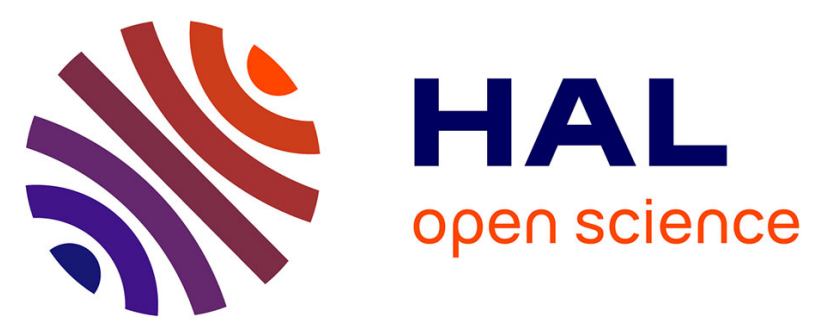

\title{
Direct metalation of heteroaromatic esters and nitriles using a mixed lithium-cadmium base. Subsequent conversion to dipyridopyrimidinones.
}

Ghenia Bentabed-Ababsa, Ely Sidaty Cheikh Sid, Stéphanie Hesse, Ekhlass

Nassar, Floris Chevallier, Tan Tai Nguyen, Aïcha Derdour, Florence Mongin

\section{To cite this version:}

Ghenia Bentabed-Ababsa, Ely Sidaty Cheikh Sid, Stéphanie Hesse, Ekhlass Nassar, Floris Chevallier, et al.. Direct metalation of heteroaromatic esters and nitriles using a mixed lithium-cadmium base. Subsequent conversion to dipyridopyrimidinones.. Journal of Organic Chemistry, 2010, 75 (3), pp.839847. 10.1021/jo902385h . hal-00785069

\section{HAL Id: hal-00785069 \\ https://hal.science/hal-00785069}

Submitted on 5 Feb 2013

HAL is a multi-disciplinary open access archive for the deposit and dissemination of scientific research documents, whether they are published or not. The documents may come from teaching and research institutions in France or abroad, or from public or private research centers.
L'archive ouverte pluridisciplinaire HAL, est destinée au dépôt et à la diffusion de documents scientifiques de niveau recherche, publiés ou non, émanant des établissements d'enseignement et de recherche français ou étrangers, des laboratoires publics ou privés. 


\section{Direct metalation of heteroaromatic esters and nitriles using a}

\section{mixed lithium-cadmium base. Subsequent conversion to}

\section{dipyridopyrimidinones}

Ghenia Bentabed-Ababsa, ${ }^{\dagger+\$}$ Sidaty Cheikh Sid Ely, ${ }^{\dagger}$ Stéphanie Hesse ${ }^{*, 8}$ Ekhlass Nassar, , ,

Floris Chevallier, ${ }^{\dagger}$ Tan Tai Nguyen, ${ }^{\dagger}$ Aïcha Derdour ${ }^{\ddagger}$ and Florence Mongin ${ }^{*}{ }^{\dagger}$

Chimie et Photonique Moléculaires, UMR 6510 CNRS, Université de Rennes 1, Bâtiment 10A, Case

1003, Campus Scientifique de Beaulieu, 35042 Rennes, France, Laboratoire de Synthèse Organique

Appliquée, Faculté des Sciences de l'Université, BP 1524 Es-Senia, Oran 31000, Algeria, Laboratoire

d'Ingéniérie Moléculaire et Biochimie Pharmacologique, Institut Jean Barriol, FR CNRS 2843,

Université Paul Verlaine-Metz, 1 Boulevard Arago, 57070 Metz Technopôle, France, Department of

Chemistry, Faculty of Women for Arts, Science and Education, Ain Shams University, Asma Fahmy

Street, Heleopolis (El-Margany), Cairo, Egypt

florence.mongin@univ-rennes1.fr

RECEIVED DATE (to be automatically inserted after your manuscript is accepted if required according to the journal that you are submitting your paper to)

${ }^{\dagger}$ Université de Rennes 1.

* Université d'Oran.

${ }^{\S}$ Université de Metz.

" Ain Shams University.

* Corresponding author. Phone: +33 22323 6931. Fax: +3322323 6955. 


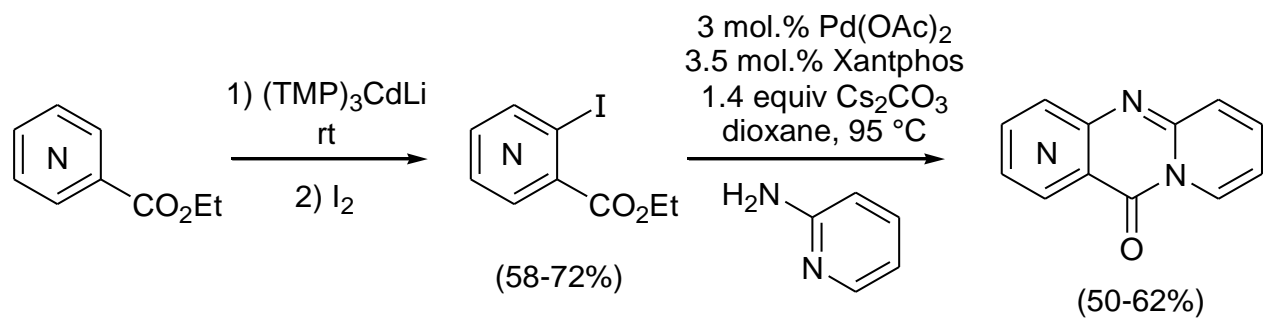

\section{Abstract:}

All pyridine nitriles and esters were metalated at the position next to the directing group using (TMP) ${ }_{3} \mathrm{CdLi}$ in tetrahydrofuran at room temperature. 2-, 3-, and 4-Cyanopyridine were treated with 0.5 equivalent of base for $2 \mathrm{~h}$ to afford, after subsequent trapping with iodine, the corresponding 3-iodo, 2iodo, and 3-iodo derivatives, respectively, in yields ranging from 30 to $61 \%$. Cyanopyrazine was similarly functionalized at the 3 position in $43 \%$ yield. Ethyl 3 -iodopicolinate and -isonicotinate were synthesized from the corresponding pyridine esters in 58 and $65 \%$ yield. Less stable ethyl 4iodonicotinate also formed under the same conditions, and was directly converted to ethyl 4-(pyrazol-1yl)nicotinate in a two steps $38 \%$ yield. All three ethyl iodopyridinecarboxylates were involved in a one pot palladium-catalyzed cross-coupling reaction/cyclization using 2-aminopyridine to afford new dipyrido[1,2- $\left.a: 3^{\prime}, 2^{\prime}-d\right]$ pyrimidin-11-one, dipyrido[1,2- $\left.a: 4^{\prime}, 3^{\prime}-d\right]$ pyrimidin-11-one and dipyrido[1,2$\left.a: 3^{\prime}, 4^{\prime}-d\right]$ pyrimidin-5-one in yields ranging from 50 to $62 \%$. A similar cross-coupling/cyclization sequence was applied to methyl 2-chloronicotinate using 2-aminopyridine, 2-amino-5-methylpyridine and 1-aminoisoquinoline to give the corresponding tricyclic or tetracyclic compounds in $43-79 \%$ yield. Dipyrido[1,2-a:4',3'-d]pyrimidin-11-one and dipyrido[1,2-a:3',4'-d]pyrimidin-5-one showed a good bactericidal activity against Pseudomonas aeroginosa. Dipyrido[1,2-a:2', $\left.3^{\prime}-d\right]$ pyrimidin-5-one and pyrido[2',3':4,5]pyrimidino[2,1-a]isoquinolin-8-one showed a fungicidal activity against Fusarium, and dipyrido[1,2-a:4',3'-d]pyrimidin-11-one against Candida albicans. Ethyl 4-(pyrazol-1-yl)nicotinate and dipyrido[1,2-a:2', $\left.3^{\prime}-d\right]$ pyrimidin-5-one have promising cytotoxic activities, the former toward a liver carcinoma cell line (HEPG2) and the latter toward a human breast carcinoma cell line (MCF7). 


\section{Introduction}

Interest in pyridine natural products and pharmaceuticals, as well as pyridine building blocks for various applications such as material science, has resulted in extensive efforts on synthesis methodologies. ${ }^{1}$ The deprotonative metalation using lithium bases has been widely used as a powerful method for the regioselective functionalization of such substrates. ${ }^{2}$ Nevertheless, the incompatibility of lithium compounds with reactive functions or sensitive heterocycles can be a limit to their use for the elaboration of complex molecules. Recourse to softer magnesium bases can improve the chemoselectivity of deprotonation reactions, but it is to the detriment of their efficiency since a large excess of base has in general to be used. ${ }^{3}$

The use of metal additives to get more efficient or more chemoselective bases (synergic superbases) has been respectively developed by Schlosser ${ }^{4}$ and Lochmann ${ }^{5}$ with LIC-KOR, mixture of butyllithium (LIC) and potassium tert-butoxide (KOR), and by Caubère, ${ }^{6}$ Gros and Fort ${ }^{7}$ in the pyridine series with BuLi-LiDMAE (DMAE = 2-dimethylaminoethoxide). More recently, other $(R)_{n}\left(R^{\prime}\right)_{n}$ 'MLi type bases, but with $\mathrm{M}$ different from an alkali metal, have been described by different groups. ${ }^{8}$ By combining alkali additives with soft organometallic compounds, bases such as $\mathrm{R}_{2} \mathrm{Zn}(\mathrm{TMP}) \mathrm{Li}(\cdot \mathrm{TMEDA})\left(\mathrm{R}={ }^{t} \mathrm{Bu}\right.$, $\mathrm{Bu}$; TMP = 2,2,6,6-tetramethylpiperidino) (described by the groups of Kondo, Uchiyama, Mulvey and Hevia), ${ }^{9}(\mathrm{TMP})_{2} \mathrm{Zn} \cdot 2 \mathrm{MgCl}_{2} \cdot 2 \mathrm{LiCl}^{10}$ and $\mathrm{TMPZnCl} \cdot \mathrm{LiCl}^{11}$ (Knochel), ${ }^{i} \mathrm{Bu}_{3} \mathrm{Al}(\mathrm{TMP}) \mathrm{Li}$ (Uchiyama and Mulvey), ${ }^{12} \mathrm{Al}(\mathrm{TMP})_{3} \cdot 3 \mathrm{LiCl} \quad($ Knochel $),{ }^{13} \quad\left(\mathrm{Me}_{3} \mathrm{SiCH}_{2}\right)_{2} \mathrm{Mn}(\mathrm{TMP}) \mathrm{Li} \cdot \mathrm{TMEDA} \quad($ Mulvey$),{ }^{14}$ and $\mathrm{MeCu}(\mathrm{TMP})(\mathrm{CN}) \mathrm{Li}_{2}$ (Uchiyama and Wheatley) ${ }^{15}$ have been prepared, characterized and used to generate functionalized aromatic compounds.

We recently accomplished the room temperature deproto-metalation of a large range of substrates including sensitive heterocycles and functionalized benzenes using a newly developed lithiumcadmium base, $(\mathrm{TMP})_{3} \mathrm{CdLi}$, prepared from $\mathrm{CdCl}_{2} \cdot \mathrm{TMEDA}$ and 3 equivalents of LiTMP. ${ }^{16}$ If TMEDA is often employed in solvents of low or modest polarities to enhance the reactivity of a base ${ }^{9 \mathrm{~d}, \mathrm{e}}$ or to 
obtain a specific regioselectivity, ${ }^{2}$ it was here rather used in order to simplify the reaction protocol, $\mathrm{CdCl}_{2} \cdot \mathrm{TMEDA}$ being much less sensitive to hydration than free $\mathrm{CdCl}_{2} \cdot{ }^{17}$

We here describe the use of $(\mathrm{TMP})_{3} \mathrm{CdLi}$ for the functionalization of pyridine esters and nitriles. Ethyl iodopyridinecarboxylates thus obtained appeared as useful key synthetic intermediates for the synthesis of polycyclic compounds containing a dipyridopyrimidinone skeleton. Some compounds were evaluated for their antimicrobial and cytotoxic activity.

\section{Results and Discussion}

\section{Synthetic aspects}

Due to their electrophilic functional group and to their ring prone to nucleophilic attacks, cyanopyridines have never been metalated at room temperature. Reactions using cyano as a group to direct ortho-lithiation have been reported in the benzene series from $1982,{ }^{18}$ but the first example in the pyridine series only appeared 20 years later. Larock and coll. showed in 2002 that it was possible to lithiate 3-cyanopyridine using LiTMP in tetrahydrofuran (THF) at $-78^{\circ} \mathrm{C}$. This result was evidenced by subsequent trapping with iodine to afford a 1:1 mixture of the 2- and 4-iodo compounds in a $50 \%$ total yield. ${ }^{19}$ Rault and coll. achieved in 2005 the regioselective ${ }^{20}$ functionalization of the other cyanopyridine isomers using 2 equivalents of the same hindered lithium amide in $\mathrm{THF}$ at $-80{ }^{\circ} \mathrm{C}$ for 0.75 h. $^{21}$

The deprotonation of cyanopyridines (1-3) as well as cyanopyrazine (4) was attempted using $(\mathrm{TMP})_{3} \mathrm{CdLi}$ in THF (Table 1), this base being suitable to metalate benzonitrile. ${ }^{16 a}$ Conducting the reaction from 2-cyanopyridine (1) using 0.5 equivalent of base at $0{ }^{\circ} \mathrm{C}$ for $2 \mathrm{~h}$ resulted, after quenching with iodine, in the formation of a mixture from which the main compound, 2-cyano-3-iodopyridine (5a), was isolated in 39\% yield (Entry 1). When the reaction was carried out at room temperature, the iodide 5a formed in 30\% yield, due to the more important formation of side products (Entry 2). By using 1 equivalent of base at room temperature, the di- and triiodide $\mathbf{5 b}, \mathbf{c}$ were obtained in 28 and $20 \%$ yield, respectively (Entry 3). If the formation of a diiodinated compound can be rationalized as the 
result of a dimetalation, $(\mathrm{TMP})_{3} \mathrm{CdLi}$ being able to dideprotonate substrates such as pyrazine, ${ }^{16 \mathrm{~b}}$ thiazole, ${ }^{16 a} N$-Boc pyrrole, ${ }^{16 a}$ thiophenes ${ }^{16 a}$ and $[1,2,3]$ triazolo[1,5- $\left.a\right]$ pyridines, ${ }^{16 c}$ the triiodide 5c could rather result from a metalation of $\mathbf{5 b}$ during the trapping step with iodine, as already suggested in the case of 3-(2-pyridyl)-[1,2,3]triazolo[1,5-a]pyridine. ${ }^{16 \mathrm{c}}$

The reaction from 4-cyanopyridine (2) was then attempted using 0.5 equivalent of base at $0{ }^{\circ} \mathrm{C}$ for 2 h; subsequent trapping with iodine afforded a mixture of 4-cyano-3-iodo- and 4-cyano-3,5diodopyridine (6a,b) in 30 and 20\% yield, respectively (Entry 4$)$. By performing the reaction at room temperature, the diiodide was not observed, but a 72:28 ratio of 4-cyano-3-iodopyridine (6a) and isomeric 4-cyano-2-iodopyridine (6c) was obtained instead, the latter being isolated in 44 and $10 \%$ yield, respectively (Entry 5). Surprisingly, carrying out the reaction with 1 equivalent of base resulted in the formation of the diiodide $\mathbf{6 d}$ under the same conditions (Entry 6).

The results obtained with 3-cyanopyridine (3) were less disappointing. Indeed, when exposed to 0.5 equivalent of base at room temperature for $2 \mathrm{~h}$, this substrate was regioselectively metalated at the 2 position. This was demonstrated by subsequent interception with iodine to afford the derivative 7 in $61 \%$ yield (Entry 7). This regioselectivity is different to that previously documented by other teams using LiTMP in THF at low temperatures; indeed, by using the lithium amide, the metalation took place unregioselectively at the positions adjacent to the cyano group. ${ }^{19,21 \text { a }}$ Such a result could be partly explained by the presence of a different directing group for the metalation using LiTMP than for that using (TMP) ${ }_{3} \mathrm{CdLi}$; whereas a first equivalent of LiTMP adds to the cyano group in the study performed by Rault and coll., it does not seem to be the case with (TMP) ${ }_{3} \mathrm{CdLi}$ (Scheme 1).

\section{SCHEME 1. 3-Cyanopyridine (3): Comparisons of the Species Before Ring Deprotonation using LiTMP and $(\mathrm{TMP})_{3} \mathrm{CdLi}$.}

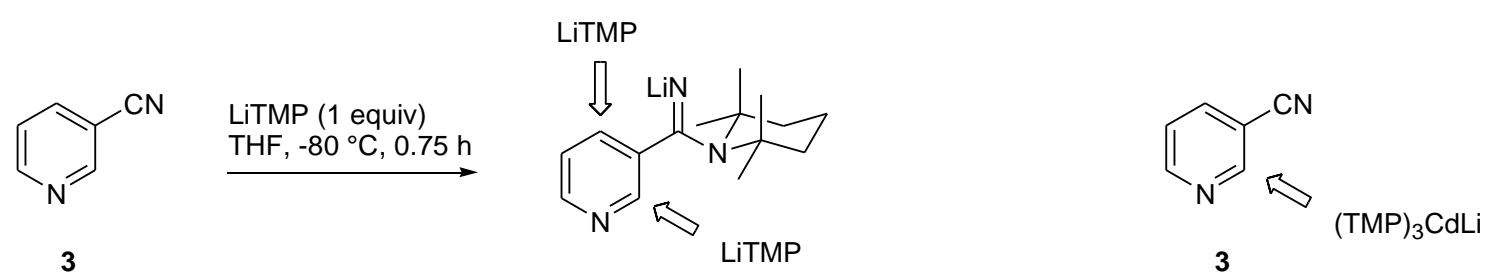


TABLE 1. Deprotonation of 1-4 using $(\mathrm{TMP})_{3}$ CdLi Followed by Trapping with $\mathrm{I}_{2}$.



$a$ Other compounds including 2-cyano-3,4diiodopyridine and 2-cyano-3,6-diiodopyridine were identified in the crude. ${ }^{b}$ Other compounds including 2-cyano-6-iodopyridine and 2-cyano-3,6diiodopyridine were identified in the crude. ${ }^{c}$ A mixture of $\mathbf{8}$ and an unidentified diiodide was obtained in a 75:25 ratio. 
These conditions were extended to cyanopyrazine (4) for which metalation mainly took place at the position next to the cyano group to furnish the iodide 8 in $43 \%$ yield (Entry 8 ).

The compatibility of an ester function with (TMP) $)_{3} \mathrm{CdLi}$ in $\mathrm{THF}$ at room temperature has been recently evidenced with the possible metalation of methyl benzoate. ${ }^{16 a}$ Using ethyl thiophene-2carboxylate (9) as substrate also resulted in its cadmation. ${ }^{22}$ After a $2 \mathrm{~h}$ contact with 0.5 equivalent of base followed by quenching with iodine, the 5-iodo derivative $\mathbf{1 0}$ was obtained in 77\% yield (Scheme 2).

SCHEME 2. Functionalization of Ethyl Thiophene-2-carboxylate (9) using (TMP) ${ }_{3} \mathrm{CdLi}$.



Deprotonation of ethyl pyridinecarboxylates is a much more difficult challenge due to easy nucleophilic attacks on their ring. In 2007, Knochel and coll. reported the magnesiation of ethyl isonicotinate using $(\mathrm{TMP})_{2} \mathrm{Mg} \cdot 2 \mathrm{LiCl}$ in $\mathrm{THF}$ at $-40{ }^{\circ} \mathrm{C}$ for $12 \mathrm{~h}$ to give, after trapping with iodine, the corresponding 3-iodo derivative in $66 \%$ yield. $^{23}$

The deprotonation of the different pyridine or pyridazine esters 11-14 was attempted using $(\mathrm{TMP})_{3} \mathrm{CdLi}$ in THF at room temperature for $2 \mathrm{~h}$, and the metalated species intercepted with iodine (Table 2). Conducting the reaction from ethyl picolinate (11) using 0.5 equivalent of base resulted in the major formation of the 3-iodo derivative 15, which was isolated in 58\% yield (Entry 1). Ethyl isonicotinate (12) similarly furnished the 3-iodo compound 16, and the yield of $65 \%$ could be slightly improved to $72 \%$ using 1 equivalent of base (Entries 2,3). Surprisingly, methyl pyridazine-4carboxylate (13) behaved differently when submitted to 0.5 equiv of base, with a complex mixture of mono- and diiodides formed (Entry 4). When treated under the same conditions, ethyl nicotinate (14) 
allowed the synthesis of the 4-iodo derivative 17 (Entry 5). The latter could not be isolated due its unstability over silica gel, but could be identified by NMR. It was involved without purification in a known copper-catalyzed reaction ${ }^{24}$ with pyrazole, to provide the expected derivative $\mathbf{1 8}$ in a two steps $38 \%$ yield (Scheme 3$)$.

TABLE 2. Deprotonation of 11-14 using $(\mathrm{TMP})_{3} \mathrm{CdLi}$ Followed by Trapping with $\mathrm{I}_{2}$.

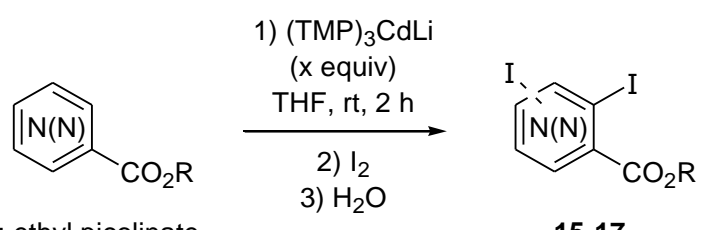

11: ethyl picolinate

12: ethyl isonicotinate

$15-17$

13: methyl pyridazine-4-carboxylate

14: ethyl nicotinate

\begin{tabular}{|c|c|c|c|c|}
\hline entry & substrate & $\mathrm{x}$ & product, yield & \\
\hline 1 & 11 & 0.5 & & $15,58 \%$ \\
\hline 2 & 12 & 0.5 & & $16,65 \%$ \\
\hline 3 & 12 & 1 & 16,7 & $72 \%$ \\
\hline 4 & 13 & 0.5 & mixture & - \\
\hline 5 & 14 & 0.5 & & $17,-$ \\
\hline
\end{tabular}

SCHEME 3. Synthesis of Ethyl 4-(pyrazol-1yl)nicotinate (18).

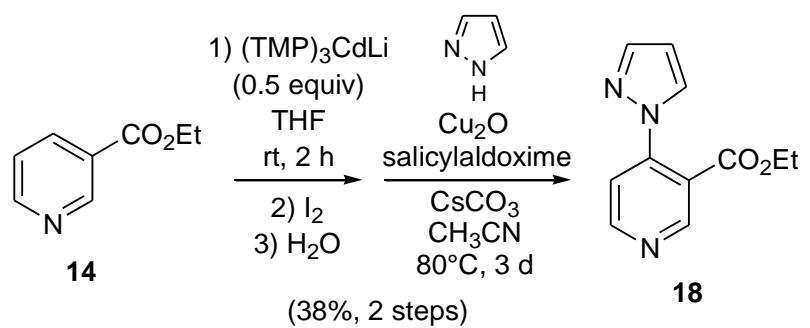

It was then decided to involve in the deprotonation-trapping sequence methyl pyridine-2,6dicarboxylate (19). By using 0.5 equivalent of (TMP) ${ }_{3} \mathrm{CdLi}$, the 3-iodo, 4-iodo and 3,4-diiodo derivatives 20-22 were obtained in a 63:28:9 ratio. Whereas the main compounds 20 and 21 were 
isolated from the mixture in 35 and 3\% yield, respectively, methyl 3,4-diiodopyridine-2,6-dicarboxylate (22) was only identified from the NMR spectra of the crude. Turning to 1 equivalent of base resulted in the formation of a fourth derivative, methyl 3,5-diiodopyridine-2,6-carboxylate (23), together with the previous iodides. It was isolated from the 22:25:4:49 mixture of the 3-iodo, 4-iodo, 3,5-diiodo and 3,4diiodo compounds in a modest $14 \%$ yield (Scheme 4$)$.

\section{SCHEME 4. Deprotonation of 19 using (TMP) $)_{3}$ CdLi Followed by Trapping with $\mathbf{I}_{2}$.}

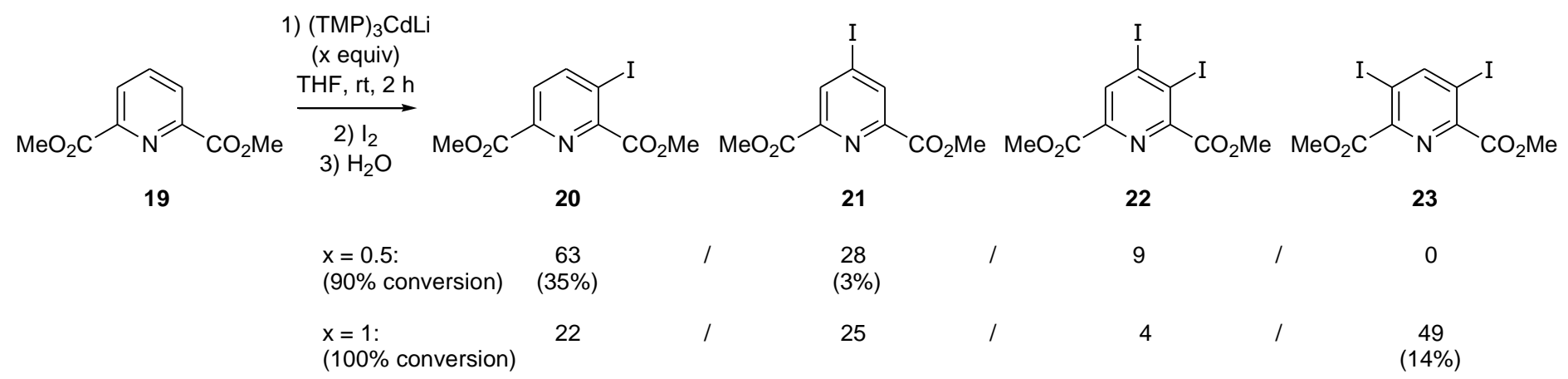

Aiming to valorize the newly synthesized ethyl iodopyridinecarboxylates $\mathbf{1 5 - 1 7}$, we studied their reactivity in palladium-catalyzed cross-coupling reactions. Especially, as done previously on ethyl halogenothiophenecarboxylates, ${ }^{25}$ we decided to couple those compounds, as well as methyl 2chloronicotinate (24), with 2-aminopyridines $\mathbf{2 5 - 2 7}$ in order to access to polycyclic compounds containing a pyridopyrimidinone moiety (Scheme 5, Table 3). Indeed, the pyridopyrimidinone core is present in number of biologically active substances. For example, aza analogues of methaqualone ${ }^{26}$ and 2-substituted-3-arylpyrido[2,3- $d$ ]pyrimidinones ${ }^{27}$ proved to be anticonvulsant agents whereas some azaquinazolinones $^{28}$ were described as antagonists of CXCR3. Aza-tryptanthrins exhibited antitrypanosomal activity ${ }^{29}$ and inhibited Plasmodium falciparum cyclin-dependent kinases. ${ }^{30}$

\section{SCHEME 5. Synthetic Scheme for the Synthesis of Tricyclic (or Tetracyclic) Compounds.}
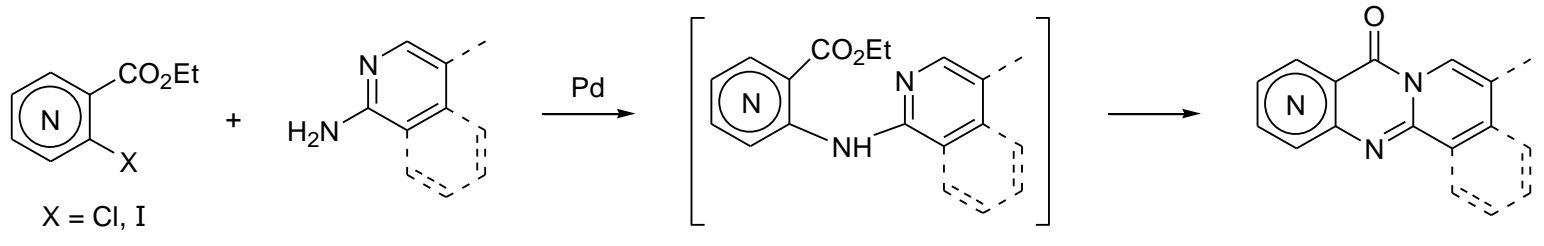
Optimization of the reaction conditions was conducted by coupling methyl 2-chloronicotinate (24) with 2-aminopyridine (25). Whereas ethyl bromothiophenecarboxylates were very sensitive to the reaction conditions (several cycles of evacuation-backfilling with argon were needed) and required high catalyst loading (7 mol.\% palladium acetate and 5 mol.\% Xantphos), halogenopyridinecarboxylates gave good results using only 3 mol.\% palladium acetate and 3.5 mol.\% Xantphos. Moreover, a simple purge of argon was sufficient. The C-N coupling followed by the intramolecular cyclization involving the nitrogen atom of the pyridine ring and the carbonyl moiety of the carboxylate took place at room temperature but in a very low yield. Turning to $55^{\circ} \mathrm{C}$ and $18 \mathrm{~h}$ of reaction allowed the formation of the expected product 28 in $20 \%$ yield. Finally, the best yield (66\%) was obtained conducting the reaction at $95^{\circ} \mathrm{C}$ for $24 \mathrm{~h}$ (Entry 1 ). Those conditions were then extended to the use of 2 -amino-5-methylpyridine (26) and 1-aminoisoquinoline (27). The methylated compound 29 was obtained after only $2.5 \mathrm{~h}$ of reaction in 79\% yield (Entry 2), and the tetracyclic compound $\mathbf{3 0}$ in a lower $43 \%$ yield (Entry 3). Involving the iodo esters $\mathbf{1 5 - 1 7}$ in the reaction similarly resulted in the formation of the tricyclic compounds 31-33 (Entries 4-6). Whereas 30-33 are new compounds, 28 and 29 were soon described in the literature; ${ }^{31}$ they were obtained thanks to a two-step process including Ullman reaction of 2halogenonicotinic acid with 2-aminopyridine-1-oxides, and subsequent intramolecular cyclization of the resulting 3-carboxy-2,2'-bipyridylamin-1'-oxides using $\mathrm{PCl}_{3}$.

TABLE 3. Buchwald-Hartwig Cross-coupling of 24, 15-17.

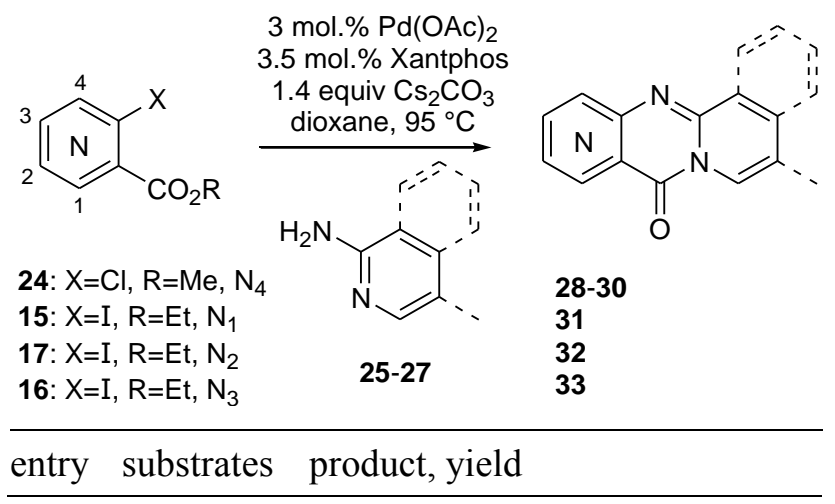




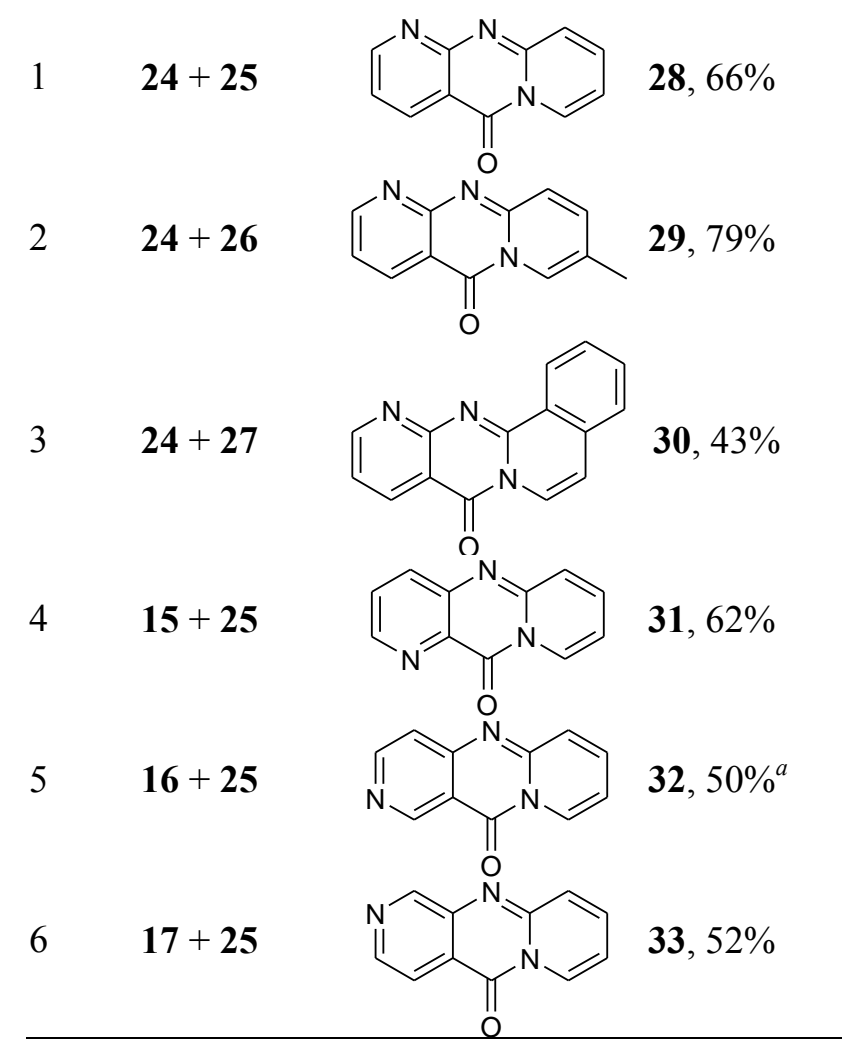

${ }^{a}$ For 2 steps.

\section{Pharmacology}

Applying the agar plate diffusion technique, ${ }^{32}$ the newly synthesized compounds $\mathbf{2 8 - 3 3}$ were screened in vitro for their bactericidal activity against Gram positive bacteria (Staphylococcus aureus) and Gram negative bacteria (Escherichia Coli and Pseudomonas aeroginosa), and for their fungicidal activity against Fusarium, Aspergillus niger and Candida albicans (Table 4). The compounds 32 and 33 showed a good bactericidal activity, similar to that of ciprofloxacin, against Pseudomonas aeroginosa whereas $\mathbf{2 8}$ and $\mathbf{3 0}$ showed a good fungicidal activity, similar to that of nystin, against Fusarium, and 32 against Candida albicans.

TABLE 4. Bactericidal and fungicidal activity of the compounds 28-33, and ciprofloxacin and nystin. ${ }^{a}$

\begin{tabular}{llllllll}
\hline entry & compound & $\begin{array}{l}\text { Staphylococcus } \\
\text { aureus }\end{array}$ & $\begin{array}{l}\text { Escherichia } \\
\text { coli }\end{array}$ & $\begin{array}{l}\text { Pseudomonas } \\
\text { aeroginosa }\end{array}$ & Fusarium & $\begin{array}{l}\text { Aspergillus } \\
\text { niger }\end{array}$ & $\begin{array}{l}\text { Candida } \\
\text { albicans }\end{array}$ \\
\hline 1 & $\mathbf{2 8}$ & $19(++)$ & - & $24(++)$ & $27(+++)$ & - & $22(++)$ \\
2 & $\mathbf{2 9}$ & $18(++)$ & - & $19(++)$ & $17(++)$ & - & $16(++)$ \\
3 & $\mathbf{3 0}$ & - & - & - & $56(++++++)$ & $18(++)$ & $19(++)$ \\
4 & $\mathbf{3 1}$ & $16(++)$ & - & - & - & - & $18(++)$
\end{tabular}




\begin{tabular}{llllllll}
5 & 32 & $17(++)$ & $18(++)$ & $25(+++)$ & $20(++)$ & - & $25(+++)$ \\
6 & $\mathbf{3 3}$ & $17(++)$ & - & $25(+++)$ & - & - & $22(++)$ \\
7 & Ciprofloxacin +++ & +++ & +++ & & & \\
8 & Nystin & & & & +++ & +++ & +++ \\
\hline
\end{tabular}

${ }^{a}$ The diameters of zones of inhibition are given in $\mathrm{mm}$. Stock solution: $5 \mu \mathrm{g}$ in $1 \mathrm{~mL}$ of DMF. $1 \mathrm{~mL}$ of stock solution in each hole of each paper disk. +: < $15 \mathrm{~mm}$;+: $15-24 \mathrm{~mm} ;+++:$ 25-34 mm; ++++: 35-44 mm, etc.

The compounds $\mathbf{1 8}$ and $\mathbf{2 8 - 3 3}$ were also tested against a human liver carcinoma cell line (HEPG2), a human breast carcinoma cell line (MCF7), and a cervix carcinoma cell line (HELA) (Table 5). Moderate cytotoxic activities were observed; the compounds $\mathbf{1 8}$ and $\mathbf{2 8}$ were found to have more promising activities toward HEPG2 and MCF7, respectively, compared to a reference drug (doxorubicin).

TABLE 5. In vitro cytotoxic activity $\left(\mathrm{IC}_{50}\right)$ of the compounds $18,28-33$, and doxorubicin against a liver carcinoma cell line (HEPG2), a human breast carcinoma cell line (MCF7), and a cervix carcinoma cell line (HELA). ${ }^{a}$

\begin{tabular}{lllll}
\hline entry & compound & HEPG2 $\left(\mu \mathrm{g} \cdot \mathrm{mL}^{-1}\right)$ & MCF7 $\left(\mu \mathrm{g} \cdot \mathrm{mL}^{-1}\right)$ & HELA $\left(\mu \mathrm{g} \cdot \mathrm{mL}^{-1}\right)$ \\
\hline 1 & $\mathbf{1 8}$ & 0.89 & 2.38 & 1.51 \\
2 & $\mathbf{2 8}$ & 1.70 & 0.78 & 1.39 \\
3 & $\mathbf{2 9}$ & 2.27 & 2.99 & 3.11 \\
4 & $\mathbf{3 0}$ & 1.77 & 1.73 & 1.09 \\
5 & $\mathbf{3 1}$ & 1.47 & 2.50 & 3.26 \\
6 & $\mathbf{3 2}$ & 1.81 & 2.34 & 2.31 \\
7 & $\mathbf{3 3}$ & 1.58 & 1.96 & 1.70 \\
8 & Doxorubicin & 0.60 & 0.70 & 0.85 \\
\hline
\end{tabular}

${ }^{a}$ IC50 is defined as the concentration which results in a 50\% decrease in cell number as compared with that of the control structures in the absence of an inhibitor.

\section{Conclusion}

All pyridine nitriles and esters were metalated at the position next to the directing group using 0.5 equivalent of $(\mathrm{TMP})_{3} \mathrm{CdLi}$ in tetrahydrofuran at room temperature for $2 \mathrm{~h}$. Subsequent trapping with iodine afforded the iodo derivatives in yields ranging from 30 to $65 \%$. The ethyl iodopyridinecarboxylates thus obtained were then involved in a one pot palladium-catalyzed crosscoupling reaction/cyclization using 2-aminopyridine to afford new polycyclic compounds containing a 
pyridopyrimidinone moiety, which were evaluated for their bactericidal and fungicidal activity. Some of the newly synthesized compounds were tested for their antitumor activity.

Because of the toxicity of cadmium compounds, ${ }^{33}$ the use of other ate bases was before considered. Polar mixtures including alkali (or alkaline-earth metal) were ruled out because of their lack of compatibility with both reactive functions and sensitive aromatic heterocycles. Lithium aluminate and cuprate were similarly discarded, sensitive heterocycles being converted with these bases at low temperatures. $^{12,15}$ The 1:1 LiTMP/(TMP) $)_{2} \mathrm{Zn}$ lithium-zinc combination, prepared from $\mathrm{ZnCl}_{2} \cdot \mathrm{TMEDA}$ and 3 equivalents of LiTMP, allows efficient deprotonation reactions of aromatic substrates. ${ }^{34}$ Nevertheless, it was not employed here because reactions using it are in general more weakly chemoselective, ${ }^{16 \mathrm{~b}}$ probably due to the presence of free LiTMP. Real lithium zincates could be more suitable for the functionalization of heteroaromatic esters and nitriles; studies in order to identify bases allowing more efficient and chemoselective reactions are currently under investigation.

\section{Experimental Section}

\section{General Procedure A (Deprotonation using 0.5 equiv $\mathrm{CdCl}_{2} \cdot \mathrm{TMEDA}$ and 1.5 equiv LiTMP}

Followed by Trapping using $\left.\mathbf{I}_{2}\right)$. To a stirred cooled $\left(0^{\circ} \mathrm{C}\right)$ solution of 2,2,6,6-tetramethylpiperidine (0.52 mL, $3.0 \mathrm{mmol})$ in THF (5 mL) were added BuLi (1.6 M hexanes solution, $3.0 \mathrm{mmol})$ and, $5 \mathrm{~min}$ later, $\mathrm{CdCl}_{2} \cdot \mathrm{TMEDA}^{35}(0.30 \mathrm{~g}, 1.0 \mathrm{mmol})$. The mixture was stirred for $10 \mathrm{~min}$ at $0{ }^{\circ} \mathrm{C}$ before introduction of the substrate $(2.0 \mathrm{mmol})$. After $2 \mathrm{~h}$ at room temperature, a solution of $\mathrm{I}_{2}(0.76 \mathrm{~g}, 3.0$ $\mathrm{mmol})$ in THF (5 mL) was added. The mixture was stirred overnight before addition of an aq saturated solution of $\mathrm{Na}_{2} \mathrm{~S}_{2} \mathrm{O}_{3}(10 \mathrm{~mL})$ and extraction with EtOAc $(3 \times 20 \mathrm{~mL})$. The combined organic layers were dried over $\mathrm{MgSO}_{4}$, filtered and concentrated under reduced pressure.

\section{General Procedure B (Deprotonation using 1.0 equiv $\mathrm{CdCl}_{2} \cdot \mathrm{TMEDA}$ and 3.0 equiv LiTMP}

Followed by Trapping using $\left.\mathbf{I}_{2}\right)$. To a stirred cooled $\left(0^{\circ} \mathrm{C}\right)$ solution of 2,2,6,6-tetramethylpiperidine (1.1 mL, $6.0 \mathrm{mmol})$ in THF $(5 \mathrm{~mL})$ were successively added BuLi (1.6 M hexanes solution, $6.0 \mathrm{mmol})$ and, 5 min later, $\mathrm{CdCl}_{2} \cdot \mathrm{TMEDA}^{35}(0.60 \mathrm{~g}, 2.0 \mathrm{mmol})$. The mixture was stirred for $10 \mathrm{~min}$ at $0{ }^{\circ} \mathrm{C}$ 
before introduction of the substrate $(2.0 \mathrm{mmol})$. After $2 \mathrm{~h}$ at room temperature, a solution of $\mathrm{I}_{2}(1.5 \mathrm{~g}$, $6.0 \mathrm{mmol})$ in THF (5 mL) was added. The mixture was stirred overnight before addition of an aq saturated solution of $\mathrm{Na}_{2} \mathrm{~S}_{2} \mathrm{O}_{3}(10 \mathrm{~mL})$ and extraction with EtOAc $(3 \times 20 \mathrm{~mL})$. The combined organic layers were dried over $\mathrm{MgSO}_{4}$, filtered and concentrated under reduced pressure.

2-Cyano-3-iodopyridine (5a). ${ }^{21 a}$ 5a was obtained according to the general procedure A starting from 2-cyanopyridine $(0.21 \mathrm{~g})$, but keeping the metallation temperature at $0{ }^{\circ} \mathrm{C}$, and was isolated after purification by flash chromatography on silica gel (eluent: heptane/EtOAc 80/20) as a white powder (0.18 g, 39\%): $\mathrm{mp} 98{ }^{\circ} \mathrm{C} ;{ }^{1} \mathrm{H}$ NMR $\left(200 \mathrm{MHz}, \mathrm{CDCl}_{3}\right) \delta 7.26(\mathrm{dd}, 1 \mathrm{H}, J=8.2$ and 4.6), $8.24(\mathrm{dd}, 1 \mathrm{H}$, $J=8.2$ and 1.4), $8.68\left(\mathrm{dd}, 1 \mathrm{H}, J=4.6\right.$ and 1.4); $\left.{ }^{13} \mathrm{C} \mathrm{NMR} \mathrm{(50} \mathrm{MHz,} \mathrm{CDCl}_{3}\right): \delta 117.4,127.5,137.9$, 138.5, 146.6, 149.4. HRMS: calcd for $\mathrm{C}_{6} \mathrm{H}_{3} \mathrm{IN}_{2}\left(\mathrm{M}^{+\bullet}\right)$ 229.9341, found 229.9345.

2-Cyano-6-iodopyridine was identified by its ${ }^{1} \mathrm{H}$ NMR spectra $\left(300 \mathrm{MHz}, \mathrm{CDCl}_{3}\right): \delta 7.49(\mathrm{t}, 1 \mathrm{H}, J$ $=7.8), 7.68(\mathrm{dd}, 1 \mathrm{H}, J=7.6$ and 1.0$), 7.95(\mathrm{dd}, 1 \mathrm{H}, J=7.8$ and 1.0$)$.

2-Cyano-3,4-diiodopyridine was identified by its ${ }^{1} \mathrm{H}$ NMR spectra $\left(300 \mathrm{MHz}, \mathrm{CDCl}_{3}\right): \delta 7.62(\mathrm{~d}, 1$ $\mathrm{H}, J=8.4), 7.79(\mathrm{~d}, 1 \mathrm{H}, J=8.4)$.

2-Cyano-3,6-diiodopyridine (5b). ${ }^{21 a} \mathbf{5 b}$ was obtained according to the general procedure B starting from 2-cyanopyridine $(0.21 \mathrm{~g})$, and isolated after purification by flash chromatography on silica gel (eluent: heptane/EtOAc 90/10) as a beige powder (0.20 g, 28\%): mp $140{ }^{\circ} \mathrm{C} ;{ }^{1} \mathrm{H} \mathrm{NMR}(300 \mathrm{MHz}$, $\left.\mathrm{CDCl}_{3}\right) \delta 7.62(\mathrm{~d}, 1 \mathrm{H}, J=8.4), 7.80(\mathrm{~d}, 1 \mathrm{H}, J=8.4) ;{ }^{13} \mathrm{C} \mathrm{NMR}\left(75 \mathrm{MHz}, \mathrm{CDCl}_{3}\right): \delta 97.7,116.3$, 116.5, 139.1, 140.0, 147.5. HRMS: calcd for $\mathrm{C}_{6} \mathrm{H}_{3} \mathrm{I}_{2} \mathrm{~N}_{2}\left([\mathrm{M}+\mathrm{H}]^{+}\right)$356.8386, found 356.8387.

2-Cyano-3,4,6-triiodopyridine (5c). 5c was obtained according to the general procedure B starting from 2-cyanopyridine $(0.21 \mathrm{~g})$, and isolated after purification by flash chromatography on silica gel (eluent: heptane/EtOAc 90/10) as a yellow powder (0.19 g, 20\%): mp $211{ }^{\circ} \mathrm{C} ;{ }^{1} \mathrm{H} \mathrm{NMR}(300 \mathrm{MHz}$, $\left.\mathrm{CDCl}_{3}\right) \delta 8.39(\mathrm{~s}, 1 \mathrm{H}) ;{ }^{13} \mathrm{C} \mathrm{NMR}\left(75 \mathrm{MHz}, \mathrm{CDCl}_{3}\right): \delta 113.2,115.9,117.0,122.4,139.7,147.1$. HRMS: calcd for $\mathrm{C}_{6} \mathrm{H}_{2} \mathrm{I}_{3} \mathrm{~N}_{2}\left([\mathrm{M}+\mathrm{H}]^{+}\right)$482.7352, found 482.7352 . 
4-Cyano-3-iodopyridine (6a). ${ }^{21 \mathrm{a}} \mathbf{6 a}$ was obtained according to the general procedure A starting from 4-cyanopyridine $(0.21 \mathrm{~g})$, and isolated after purification by flash chromatography on silica gel (eluent: heptane/EtOAc 70/30) as a beige powder (0.20 g, 44\%): mp $122{ }^{\circ} \mathrm{C} ;{ }^{1} \mathrm{H}$ NMR $\left(200 \mathrm{MHz}, \mathrm{CDCl}_{3}\right) \delta$ $7.52\left(\mathrm{dd}, 1 \mathrm{H}, J=4.8\right.$ and 0.6), $8.71(\mathrm{~d}, 1 \mathrm{H}, J=5.0), 9.10(\mathrm{~s}, 1 \mathrm{H}) ;{ }^{13} \mathrm{C} \mathrm{NMR}\left(75 \mathrm{MHz}, \mathrm{CDCl}_{3}\right): \delta 96.4$, 117.0, 127.1, 127.9, 148.9, 158.0. HRMS: calcd for $\mathrm{C}_{6} \mathrm{H}_{3} \mathrm{IN}_{2}\left(\mathrm{M}^{+\bullet}\right)$ 229.9341, found 229.9345.

4-Cyano-3,5-diiodopyridine (6b). ${ }^{21 a} 6 \mathbf{b}$ was obtained according to the general procedure A starting from 4-cyanopyridine $(0.21 \mathrm{~g})$, but keeping the metallation temperature at $0{ }^{\circ} \mathrm{C}$, and was isolated after purification by flash chromatography on silica gel (eluent: heptane/EtOAc 90/10) as a beige powder (0.14 g, 20\%): mp $153{ }^{\circ} \mathrm{C} ;{ }^{1} \mathrm{H}$ NMR $\left(300 \mathrm{MHz}, \mathrm{CDCl}_{3}\right) \delta 8.97$ (s, $\left.2 \mathrm{H}\right) ;{ }^{13} \mathrm{C} \mathrm{NMR}\left(75 \mathrm{MHz}, \mathrm{CDCl}_{3}\right): \delta$ 97.3 (2C), 118.4, 134.5, 156.4 (2C). HRMS: calcd for $\mathrm{C}_{6} \mathrm{H}_{2} \mathrm{I}_{2} \mathrm{~N}_{2} \mathrm{Na}\left([\mathrm{M}+\mathrm{Na}]^{+}\right) 378.8205$, found 378.8207 .

4-Cyano-2-iodopyridine (6c). ${ }^{36}$ 6c was obtained according to the general procedure A starting from 4-cyanopyridine $(0.21 \mathrm{~g})$, and isolated after purification by flash chromatography on silica gel (eluent: heptane/EtOAc 70/30) as a beige powder (46 mg, 10\%): $\mathrm{mp} 76{ }^{\circ} \mathrm{C} ;{ }^{1} \mathrm{H} \mathrm{NMR}\left(300 \mathrm{MHz}, \mathrm{CDCl}_{3}\right) \delta 7.50$ $\left(\mathrm{dd}, 1 \mathrm{H}, J=5.0\right.$ and 1.4), $7.96(\mathrm{t}, 1 \mathrm{H}, J=1.4), 8.56(\mathrm{dd}, 1 \mathrm{H}, J=5.0$ and 1.4$) ;{ }^{13} \mathrm{C} \mathrm{NMR}(75 \mathrm{MHz}$, $\left.\mathrm{CDCl}_{3}\right): \delta 114.6,117.8,121.5,124.1,136.0,151.3 . \mathrm{HRMS}$ : calcd for $\mathrm{C}_{6} \mathrm{H}_{3} \mathrm{IN}_{2}\left(\mathrm{M}^{+\bullet}\right) 229.9341$, found 229.9345 .

4-Cyano-2,3-diiodopyridine (6d). 6d was obtained according to the general procedure B starting from 4-cyanopyridine $(0.21 \mathrm{~g})$, and isolated after purification by flash chromatography on silica gel (eluent: heptane/EtOAc 80/20) as a beige powder (0.36 g, 51\%): mp $215{ }^{\circ} \mathrm{C} ;{ }^{1} \mathrm{H} \mathrm{NMR}(300 \mathrm{MHz}$, $\left.\mathrm{CDCl}_{3}\right) \delta 7.84(\mathrm{~d}, 1 \mathrm{H}, J=5.3), 8.08(\mathrm{~d}, 1 \mathrm{H}, J=5.3) ;{ }^{13} \mathrm{C} \mathrm{NMR}\left(75 \mathrm{MHz}, \mathrm{CDCl}_{3}\right): \delta 110.6,119.1$, 121.0, 127.1, 133.1, 151.7. HRMS: calcd for $\mathrm{C}_{6} \mathrm{H}_{2} \mathrm{I}_{2} \mathrm{~N}_{2}\left(\mathrm{M}^{+\bullet}\right)$ 355.8307, found 355.8341 .

3-Cyano-2-iodopyridine (7). 7 was obtained according to the general procedure A starting from 3cyanopyridine $(0.21 \mathrm{~g})$, and isolated after purification by flash chromatography on silica gel (eluent: heptane/EtOAc 80/20) as a beige powder (0.28 g, 61\%): mp $127{ }^{\circ} \mathrm{C} ;{ }^{1} \mathrm{H}$ NMR $\left(200 \mathrm{MHz}, \mathrm{CDCl}_{3}\right) \delta$ 
$7.43\left(\mathrm{dd}, 1 \mathrm{H}, J=7.7\right.$ and 4.9), $7.82(\mathrm{dd}, 1 \mathrm{H}, J=7.7$ and 2.0$), 8.54(\mathrm{dd}, 1 \mathrm{H}, J=4.9$ and 2.0$) ;{ }^{13} \mathrm{C}$ NMR $\left(50 \mathrm{MHz}, \mathrm{CDCl}_{3}\right): \delta 117.7,119.9,121.0,122.5,141.2,152.9 . \mathrm{HRMS}:$ calcd for $\mathrm{C}_{6} \mathrm{H}_{3} \mathrm{IN}_{2}\left(\mathrm{M}^{+\bullet}\right)$ 229.9341, found 229.9345. These data are analogous to those previously described. ${ }^{19}$

2-Cyano-3-iodopyrazine (8). ${ }^{37} \mathbf{8}$ was obtained according to the general procedure A starting from cyanopyrazine $(0.21 \mathrm{~g})$, and isolated after purification by flash chromatography on silica gel (eluent: heptane/EtOAc 90/10) as a yellow powder (0.20 g, 43\%): mp $107{ }^{\circ} \mathrm{C} ;{ }^{1} \mathrm{H} \mathrm{NMR}\left(300 \mathrm{MHz}, \mathrm{CDCl}_{3}\right) \delta$ $8.54(\mathrm{~d}, 1 \mathrm{H}, J=2.4), 8.65(\mathrm{~d}, 1 \mathrm{H}, J=2.4) ;{ }^{13} \mathrm{C} \mathrm{NMR}\left(75 \mathrm{MHz}, \mathrm{CDCl}_{3}\right): \delta 116.3,120.7,138.2,143.2$, 147.2. HRMS: calcd for $\mathrm{C}_{5} \mathrm{H}_{2} \mathrm{IN}_{3} \mathrm{Na}\left([\mathrm{M}+\mathrm{Na}]^{+}\right)$253.9191, found 253.9192 .

Ethyl 5-iodothiophene-2-carboxylate (10). 10 was obtained according to the general procedure A starting from ethyl thiophene-2-carboxylate $(0.31 \mathrm{~g})$, and isolated after purification by flash chromatography on silica gel (eluent: heptane $\left./ \mathrm{CH}_{2} \mathrm{Cl}_{2} 90 / 10\right)$ as a yellow oil $(0.43 \mathrm{~g}, 77 \%):{ }^{1} \mathrm{H}$ NMR $\left(300 \mathrm{MHz}, \mathrm{CDCl}_{3}\right) \delta 1.36(\mathrm{t}, 3 \mathrm{H}, J=7.1), 4.33(\mathrm{q}, 2 \mathrm{H}, J=7.1), 7.25(\mathrm{~d}, 1 \mathrm{H}, J=3.9), 7.42(\mathrm{~d}, 1 \mathrm{H}, J$ = 3.9). These data are similar to those described. ${ }^{22}{ }^{13} \mathrm{C} \mathrm{NMR}\left(75 \mathrm{MHz}, \mathrm{CDCl}_{3}\right): \delta 14.4,61.5,82.6$, $134.4,137.8,139.8,161.0$.

Ethyl 3-iodopicolinate (15). ${ }^{38} 15$ was obtained according to the general procedure A starting from ethyl picolinate $(0.30 \mathrm{~g})$, and isolated after purification by flash chromatography on silica gel (eluent: heptane/EtOAc 80/20) as a yellow oil (0.32 g, 58\%): ${ }^{1} \mathrm{H}$ NMR $\left(200 \mathrm{MHz}, \mathrm{CDCl}_{3}\right) \delta 1.45(\mathrm{t}, 3 \mathrm{H}, J=$ 7.1), 4.47 (q, $2 \mathrm{H}, J=7.1), 7.11(\mathrm{dd}, 1 \mathrm{H}, J=8.2$ and 4.7), $8.25(\mathrm{dd}, 1 \mathrm{H}, J=8.2$ and 1.4), 8.62 (dd, 1 $\mathrm{H}, J=4.7$ and 1.4); ${ }^{13} \mathrm{C} \mathrm{NMR}\left(50 \mathrm{MHz}, \mathrm{CDCl}_{3}\right): \delta 14.1,62.1,92.1,126.1,126.2,148.2,152.3,165.7$. HRMS: calcd for $\mathrm{C}_{8} \mathrm{H}_{8} \mathrm{INO}_{2}\left(\mathrm{M}^{+\bullet}\right)$ 276.9600, found 276.9609 .

Ethyl 3-iodoisonicotinate (16). ${ }^{23} 16$ was obtained according to the general procedure A starting from ethyl isonicotinate $(0.30 \mathrm{~g})$, and isolated after purification by flash chromatography on silica gel (eluent: heptane/EtOAc 80/20) as an orange oil (0.36 g, 65\%): ${ }^{1} \mathrm{H}$ NMR $\left(200 \mathrm{MHz}, \mathrm{CDCl}_{3}\right) \delta 1.41(\mathrm{t}, 3 \mathrm{H}, J=$ 7.1), $4.42(\mathrm{q}, 2 \mathrm{H}, J=7.1), 7.62(\mathrm{~d}, 1 \mathrm{H}, J=4.9), 8.60(\mathrm{~d}, 1 \mathrm{H}, J=4.8), 9.08(\mathrm{~s}, 1 \mathrm{H}) ;{ }^{13} \mathrm{C}$ NMR $(50$ 
$\left.\mathrm{MHz}, \mathrm{CDCl}_{3}\right): \delta 14.0,62.4,92.3,124.3,142.3,149.0,159.4,164.9 . \mathrm{HRMS}:$ calcd for $\mathrm{C}_{8} \mathrm{H}_{8} \mathrm{INO}_{2}\left(\mathrm{M}^{+\bullet}\right)$ 276.9600 , found 276.9609 .

Methyl 3-iodopyridazine-4-carboxylate. A pure fraction was isolated (eluent: heptane/EtOAc 85/15) from the crude obtained according to the general procedure A as a yellow solid (degradation to a dark residue upon standing): ${ }^{1} \mathrm{H}$ NMR $\left(300 \mathrm{MHz}, \mathrm{CDCl}_{3}\right): \delta 7.66(\mathrm{~d}, 1 \mathrm{H}, J=5.0), 9.26(\mathrm{~d}, 1 \mathrm{H}, J=$ 5.0), $4.01(\mathrm{~s}, 3 \mathrm{H}) ;{ }^{13} \mathrm{C} \mathrm{NMR}\left(75 \mathrm{MHz}, \mathrm{CDCl}_{3}\right): \delta 53.7,77.4,126.2,135.3,150.6,164.4$.

Methyl 3,5-diiodopyridazine-4-carboxylate. A pure fraction was isolated (eluent: heptane/EtOAc $85 / 15$ ) from the crude obtained according to the general procedure A as a yellow solid (degradation to a dark residue upon standing): ${ }^{1} \mathrm{H}$ NMR $\left(300 \mathrm{MHz}, \mathrm{CDCl}_{3}\right): \delta 9.41(\mathrm{~s}, 1 \mathrm{H}), 4.03(\mathrm{~s}, 3 \mathrm{H}) ;{ }^{13} \mathrm{C}$ NMR $(75$ $\left.\mathrm{MHz}, \mathrm{CDCl}_{3}\right): \delta 54.1,97.4,120.2,145.6,157.9,165.4$.

Ethyl 4-iodonicotinate (17). 17 was obtained according to the general procedure A starting from ethyl nicotinate $(0.30 \mathrm{~g})$, but could not be purified by flash chromatography on silica gel because of its low stability. It was identified by NMR: ${ }^{1} \mathrm{H}$ NMR $\left(200 \mathrm{MHz}, \mathrm{CDCl}_{3}\right) \delta 1.42(\mathrm{t}, 3 \mathrm{H}, J=7.1), 4.14(\mathrm{q}, 2$ $\mathrm{H}, J=7.1), 7.94(\mathrm{~d}, 1 \mathrm{H}, J=5.3), 8.23(\mathrm{~d}, 1 \mathrm{H}, J=5.3), 8.93(\mathrm{~s}, 1 \mathrm{H}) .{ }^{13} \mathrm{C} \mathrm{NMR}\left(50 \mathrm{MHz}, \mathrm{CDCl}_{3}\right): \delta$ $14.1,62.1,106.1,131.0,136.2,151.0,152.0,164.7$. The crude was directly involved in the reactions giving the compounds $\mathbf{1 8}$ and $\mathbf{3 2}$.

Ethyl 4-(pyrazol-1-yl)nicotinate (18). 18 was obtained from the crude compound 17 by adapting a procedure described, ${ }^{24}$ and was isolated after purification by flash chromatography on silica gel (eluent: heptane/EtOAc 70/30) as an orange oil (0.17 g, 2 steps, 38\%): ${ }^{1} \mathrm{H}$ NMR (300 MHz, $\left.\mathrm{CDCl}_{3}\right) \delta 1.24(\mathrm{t}, 3$ $\mathrm{H}, J=7.1), 4.31(\mathrm{q}, 2 \mathrm{H}, J=7.2), 6.50(\mathrm{dd}, 1 \mathrm{H}, J=2.4$ and 1.8), $7.48(\mathrm{~d}, 1 \mathrm{H}, J=5.4), 7.75(\mathrm{~d}, 1 \mathrm{H}, J$ $=1.5), 7.83(\mathrm{~d}, 1 \mathrm{H}, J=2.7), 8.75(\mathrm{~d}, 1 \mathrm{H}, J=5.1), 8.92(\mathrm{~s}, 1 \mathrm{H}) ;{ }^{13} \mathrm{C} \mathrm{NMR}\left(75 \mathrm{MHz}, \mathrm{CDCl}_{3}\right): \delta 14.1$, $62.1,108.8,117.1,121.9,129.5,142.6,145.1,151.5,152.9,165.9$. HRMS: calcd for $\mathrm{C}_{11} \mathrm{H}_{12} \mathrm{~N}_{3} \mathrm{O}_{2}$ $\left([\mathrm{M}+\mathrm{H}]^{+}\right)$218.0930, found 218.0932 . 
Methyl 3-iodopyridine-2,6-dicarboxylate (20). 20 was obtained according to the general procedure A starting from methyl pyridine-2,6-dicarboxylate $(0.39 \mathrm{~g})$, and isolated by flash chromatography on silica gel (eluent: heptane/ $\left.\mathrm{CH}_{2} \mathrm{Cl}_{2} 80 / 20\right)$ as a pale orange powder $(0.22 \mathrm{~g}, 35 \%)$ : mp $88-90{ }^{\circ} \mathrm{C} ;{ }^{1} \mathrm{H}$ NMR $\left(300 \mathrm{MHz}, \mathrm{CDCl}_{3}\right) \delta 4.00(\mathrm{~s}, 3 \mathrm{H}), 4.01(\mathrm{~s}, 3 \mathrm{H}), 7.89(\mathrm{~d}, 1 \mathrm{H}, J=8.1), 8.42(\mathrm{~d}, 1 \mathrm{H}, J=8.1) ;{ }^{13} \mathrm{C}$ NMR (50 MHz, $\left.\mathrm{CDCl}_{3}\right): \delta 53.3$ (2C), 95.3, 127.1, 146.8, 149.6, 152.6, 164.7, 165.5. HRMS: calcd for $\mathrm{C}_{9} \mathrm{H}_{8} \mathrm{INO}_{4}\left(\mathrm{M}^{+\bullet}\right) 320.9498$, found 320.9496.

Methyl 4-iodopyridine-2,6-dicarboxylate (21). 21 was obtained according to the general procedure A starting from methyl pyridine-2,6-dicarboxylate $(0.39 \mathrm{~g})$, and isolated by flash chromatography on silica gel (eluent: heptane $\left./ \mathrm{CH}_{2} \mathrm{Cl}_{2} 80 / 20\right)$ in $3 \%(18 \mathrm{mg})$ yield: ${ }^{1} \mathrm{H} \mathrm{NMR}\left(300 \mathrm{MHz}, \mathrm{CDCl}_{3}\right) \delta 4.02(\mathrm{~s}$, $6 \mathrm{H}), 8.66(\mathrm{~s}, 2 \mathrm{H}) .{ }^{13} \mathrm{C}$ NMR $\left(50 \mathrm{MHz}, \mathrm{CDCl}_{3}\right): \delta 53.2(2 \mathrm{C}), 106.8,136.9(2 \mathrm{C}), 148.0(2 \mathrm{C}), 163.6(2 \mathrm{C})$. These data are similar to those previously described. ${ }^{39} \mathrm{HRMS}$ : calcd for $\mathrm{C}_{7} \mathrm{H}_{6} \mathrm{INO}_{2}\left[\left(\mathrm{M}-\mathrm{C}_{2} \mathrm{H}_{2} \mathrm{O}_{2}\right)^{+\bullet}\right]$ 262.9443, found 262.9469.

Methyl 3,4-diiodopyridine-2,6-dicarboxylate (22). 22 formed using the general procedure A and B, and was identified by its NMR data: ${ }^{1} \mathrm{H}$ NMR $\left(300 \mathrm{MHz}, \mathrm{CDCl}_{3}\right) \delta 3.98(\mathrm{~s}, 6 \mathrm{H}), 8.88(\mathrm{~s}, 1 \mathrm{H})$. HRMS: calcd for $\mathrm{C}_{8} \mathrm{H}_{5} \mathrm{I}_{2} \mathrm{NO}_{3}\left[\left(\mathrm{M}-\mathrm{CH}_{2} \mathrm{O}\right)^{+\bullet}\right]$ and $\mathrm{C}_{7} \mathrm{H}_{5} \mathrm{I}_{2} \mathrm{NO}_{2}\left[\left(\mathrm{M}-\mathrm{C}_{2} \mathrm{H}_{2} \mathrm{O}_{2}\right)^{+\bullet}\right] 416.8359$ and 388.8410, found 416.8379 and 388.8426.

Methyl 3,5-diiodopyridine-2,6-dicarboxylate (23). 23 was obtained according to the general procedure B starting from methyl pyridine-2,6-dicarboxylate $(0.39 \mathrm{~g})$, and isolated by flash chromatography on silica gel (eluent: heptane $\left./ \mathrm{CH}_{2} \mathrm{Cl}_{2} 80 / 20\right)$ as a beige powder $(0.13 \mathrm{~g}, 14 \%)$ : mp $128-$ $130{ }^{\circ} \mathrm{C} ;{ }^{1} \mathrm{H}$ NMR $\left(300 \mathrm{MHz}, \mathrm{CDCl}_{3}\right) \delta 3.99(\mathrm{~s}, 6 \mathrm{H}), 8.88(\mathrm{~s}, 1 \mathrm{H}) ;{ }^{13} \mathrm{C} \mathrm{NMR}\left(50 \mathrm{MHz}, \mathrm{CDCl}_{3}\right): \delta 53.4$ (2C), 93.4 (2C), 150.6, 159.5, 164.9 (2C). HRMS: calcd for $\mathrm{C}_{9} \mathrm{H}_{7} \mathrm{I}_{2} \mathrm{NO}_{4}\left(\mathrm{M}^{+\bullet}\right)$ 446.8465, found 446.8447.

General Procedure C for Buchwald-Hartwig Cross-coupling. A solution of $\mathrm{Pd}(\mathrm{OAc})_{2}(10 \mathrm{mg}, 3$ mol\%), Xantphos (30 mg, $3.5 \mathrm{~mol} \%$ ) and $\mathrm{Cs}_{2} \mathrm{CO}_{3}$ (675 mg, 1.4 equiv) was prepared under argon in dioxane. When the temperature reached $55^{\circ} \mathrm{C}$, the appropriate halogenopyridine $(1.5 \mathrm{mmol}, 1$ equiv $)$ 
was added under argon and then 5 to 10 minutes later (temperature about $80{ }^{\circ} \mathrm{C}$ ), the aminopyridine (1.8 mmol, 1.2 equiv) was finally introduced. The reaction mixture was stirred at $95{ }^{\circ} \mathrm{C}$ for $2.5 \mathrm{~h}$ to $24 \mathrm{~h}$ under argon (reaction was followed by thin layer chromatography). After cooling to room temperature, the reaction mixture was filtered, and the cake was washed with EtOAc. The filtrate was concentrated under reduced pressure.

Dipyrido[1,2-a:2',3'-d]pyrimidin-5-one (28). 28 was obtained according to the general procedure C starting from methyl 2-chloronicotinate $(0.26 \mathrm{~g})$ and 2-aminopyridine $(0.17 \mathrm{~g})$, and was isolated after purification by chromatography on silica gel $\left(\mathrm{CHCl}_{3}\right.$ as eluent) as a yellow solid $(0.20 \mathrm{~g}, 66 \%)$ : $\mathrm{mp}$ 220-221 ${ }^{\circ} \mathrm{C}\left(\right.$ lit. $\left.^{40} 223{ }^{\circ} \mathrm{C}\right) ;{ }^{1} \mathrm{H}$ NMR $\left(250 \mathrm{MHz}, \mathrm{CDCl}_{3}\right) \delta 6.99$ (m, $\left.1 \mathrm{H}\right), 7.43$ (dd, $1 \mathrm{H}, J=8.0$ and 4.4), 7.64-7.69 (m, 2H), $8.78(\mathrm{dd}, 1 \mathrm{H}, J=8.0$ and 2.1), $8.89(\mathrm{~m}, 1 \mathrm{H}), 9.12(\mathrm{dd}, 1 \mathrm{H}, J=4.4$ and 2.1); ${ }^{13} \mathrm{C}$ NMR $\left(62.5 \mathrm{MHz}, \mathrm{CDCl}_{3}\right) \delta 111.3,113.5,120.6,126.7,127.0,135.7,137.0,149.8,157.4,157.8$, 159.7; IR $(\mathrm{KBr}) \vee 1698,1641,1593,1543,1526,1411 \mathrm{~cm}^{-1}$; HRMS: calcd for $\mathrm{C}_{11} \mathrm{H}_{8} \mathrm{~N}_{3} \mathrm{O}\left([\mathrm{M}+\mathrm{H}]^{+}\right)$ 198.0662, found 198.0668.

8-Methyldipyrido[1,2-a:2',3'-d]pyrimidin-5-one (29). 29 was obtained according to the general procedure $\mathrm{C}$ starting from methyl 2-chloronicotinate $(0.26 \mathrm{~g})$ and 2-amino-5-methylpyridine $(0.19 \mathrm{~g})$, and was isolated after purification by chromatography on silica gel $\left(\mathrm{CHCl}_{3}\right.$ as eluent) as a yellow solid (0.25 g, 79\%): mp 201-202 ${ }^{\circ} \mathrm{C}\left(\right.$ lit. $\left.^{40} 203{ }^{\circ} \mathrm{C}\right) ;{ }^{1} \mathrm{H}$ NMR $\left(250 \mathrm{MHz}, \mathrm{CDCl}_{3}\right) \delta 2.48(\mathrm{~s}, 3 \mathrm{H}), 6.82(\mathrm{dd}, 1$ $\mathrm{H}, J=7.5$ and 1.8), $7.38(\mathrm{dd}, 1 \mathrm{H}, J=8.0$ and 4.4), $7.45($ br s, $1 \mathrm{H}), 8.74(\mathrm{dd}, 1 \mathrm{H}, J=8.0$ and 2.1), 8.79 $(\mathrm{d}, 1 \mathrm{H}, J=7.5), 9.08(\mathrm{dd}, 1 \mathrm{H}, J=4.4$ and 2.1$) ;{ }^{13} \mathrm{C} \mathrm{NMR}\left(62.5 \mathrm{MHz}, \mathrm{CDCl}_{3}\right) \delta$ 21.6, 110.9, 116.5, $120.1,124.4,126.0,137.0,147.8,149.9,157.7,157.8,159.8$; IR (KBr) v 1693, 1651, 1592, 1543, 1412 $\mathrm{cm}^{-1}$; HRMS: calcd for $\mathrm{C}_{12} \mathrm{H}_{10} \mathrm{~N}_{3} \mathrm{O}\left([\mathrm{M}+\mathrm{H}]^{+}\right)$212.0818, found 212.0826.

Pyrido[2',3':4,5]pyrimidino[2,1-a]isoquinolin-8-one (30). 30 was obtained according to the general procedure $\mathrm{C}$ starting from methyl 2-chloronicotinate $(0.26 \mathrm{~g})$ and 1 -aminoisoquinoline $(0.26 \mathrm{~g})$, and was isolated after purification by chromatography on silica gel (eluent: EtOAc/ $\mathrm{C}_{6} \mathrm{H}_{12} 70 / 30$ ) as a yellow solid (95 mg, 43\%): mp 242-244 ${ }^{\circ} \mathrm{C} ;{ }^{1} \mathrm{H}$ NMR (250 MHz, $\left.\mathrm{CDCl}_{3}\right) \delta 7.17(\mathrm{~d}, 1 \mathrm{H}, J=7.8), 7.48(\mathrm{dd}, 1$ 
$\mathrm{H}, J=8.0$ and 4.5), 7.70-7.83 (m, $3 \mathrm{H}), 8.67(\mathrm{~d}, 1 \mathrm{H}, J=7.8), 8.81(\mathrm{dd}, 1 \mathrm{H}, J=8.0$ and 2.1), $9.13(\mathrm{dd}$, $1 \mathrm{H}, J=4.5$ and 2.1); $9.30(\mathrm{~d}, 1 \mathrm{H}, J=8.0) ;{ }^{13} \mathrm{C} \mathrm{NMR}\left(62.5 \mathrm{MHz}, \mathrm{CDCl}_{3}\right) \delta 112.8,114.2,121.2,121.5$, $126.5,127.0,128.2,128.9,133.1,133.4,137.0,149.1,156.9,157.2,160.1 ; \mathrm{IR}(\mathrm{KBr}) \vee 1679,1645$, 1593, 1555, $1423 \mathrm{~cm}^{-1}$; HRMS: calcd for $\mathrm{C}_{15} \mathrm{H}_{10} \mathrm{~N}_{3} \mathrm{O}\left([\mathrm{M}+\mathrm{H}]^{+}\right)$248.0818, found 248.0808.

Dipyrido[1,2-a:3',2'-d]pyrimidin-11-one (31). 31 was obtained according to the general procedure C starting from ethyl 3-iodopicolinate $(0.42 \mathrm{~g})$ and 2-aminopyridine $(0.17 \mathrm{~g})$, and was isolated after purification by chromatography on silica gel $\left(\mathrm{CHCl}_{3}\right.$ as eluent) as a yellow solid ( $\left.0.12 \mathrm{~g}, 62 \%\right)$ : $\mathrm{mp} 211$ ${ }^{\circ} \mathrm{C} ;{ }^{1} \mathrm{H}$ NMR $\left(250 \mathrm{MHz}, \mathrm{CDCl}_{3}\right) \delta$ 6.94-7.00 (m, $\left.1 \mathrm{H}\right), 7.55-7.67(\mathrm{~m}, 2 \mathrm{H}), 7.75(\mathrm{dd}, 1 \mathrm{H}, J=8.5$ and 4.1), $8.14\left(\mathrm{dd}, 1 \mathrm{H}, J=8.5\right.$ and 1.5), $8.91(\mathrm{dd}, 1 \mathrm{H}, J=4.1$ and 1.5$), 9.00-9.04(\mathrm{~m}, 1 \mathrm{H}) ;{ }^{13} \mathrm{C}$ NMR $(62.5$ $\left.\mathrm{MHz}, \mathrm{CDCl}_{3}\right) \delta 113.1,126.3,127.4,129.0,132.5,135.1,135.3,145.6,148.2,148.9,157.7 ; \mathrm{IR}(\mathrm{KBr}) v$ 1702, 1641, 1543, 1519, 1469, $1413 \mathrm{~cm}^{-1}$; HRMS: calcd for $\mathrm{C}_{11} \mathrm{H}_{8} \mathrm{~N}_{3} \mathrm{O}\left([\mathrm{M}+\mathrm{H}]^{+}\right) 198.0662$, found 198.0662.

Dipyrido[1,2-a:4',3'-d]pyrimidin-11-one (32). 32 was obtained according to the general procedure C starting from crude ethyl 4-iodonicotinate (general procedure A) and 2-aminopyridine $(0.23 \mathrm{~g})$, and was isolated after purification by chromatography on silica gel (eluent: $\mathrm{CH}_{2} \mathrm{Cl}_{2} / \mathrm{Et}_{3} \mathrm{~N}$ 98/2) as a brown solid (0.20 g, 50\% for 2 steps): $\mathrm{mp} 130{ }^{\circ} \mathrm{C} ;{ }^{1} \mathrm{H}$ NMR $\left(300 \mathrm{MHz}, \mathrm{CDCl}_{3}\right) \delta 6.99(\mathrm{~m}, 1 \mathrm{H}), 7.54(\mathrm{~m}, 2 \mathrm{H})$, $7.68\left(\mathrm{ddd}, 1 \mathrm{H}, J=9.2,6.5\right.$ and 1.6), $8.80(\mathrm{~d}, 1 \mathrm{H}, J=6.0), 8.93(\mathrm{~m}, 1 \mathrm{H}), 9.64(\mathrm{~s}, 1 \mathrm{H}) .{ }^{13} \mathrm{C}$ NMR $(75$ $\left.\mathrm{MHz}, \mathrm{CDCl}_{3}\right) \delta 111.9,113.7,119.7,126.4,127.2,139.4,151.1,152.0,152.7,152.9,158.2$. HRMS: calcd for $\mathrm{C}_{11} \mathrm{H}_{7} \mathrm{~N}_{3} \mathrm{O}\left([\mathrm{M}+\mathrm{H}]^{+}\right)$198.0667, found 198.0670.

Dipyrido[1,2-a:3',4'-d]pyrimidin-5-one (33). 33 was obtained according to the general procedure C starting from ethyl 3-iodoisonicotinate $(0.42 \mathrm{~g})$ and 2 -aminopyridine $(0.17 \mathrm{~g})$, and was isolated after purification by chromatography on silica gel (eluent: $\mathrm{CH}_{2} \mathrm{Cl}_{2} / \mathrm{Et}_{3} \mathrm{~N}$ 98/2) as an orange solid $(0.15 \mathrm{~g}$, 52\%): mp $164{ }^{\circ} \mathrm{C} ;{ }^{1} \mathrm{H}$ NMR $\left(300 \mathrm{MHz}, \mathrm{CDCl}_{3}\right) \delta 6.96(\mathrm{~m}, 1 \mathrm{H}), 7.59(\mathrm{~m}, 2 \mathrm{H}), 8.14(\mathrm{dd}, 1 \mathrm{H}, J=5.4$ and 0.7), $8.62($ br d, $1 \mathrm{H}, J=5.4), 8.86(\mathrm{dt}, 1 \mathrm{H}, J=7.4$ and 1.2), 9.25 (br s, $1 \mathrm{H}) .{ }^{13} \mathrm{C} \mathrm{NMR}\left(75 \mathrm{MHz}, \mathrm{CDCl}_{3}\right)$ 
$\delta 113.8,118.6,120.2,126.8,127.0,135.1,143.1,143.7,149.1,151.9,158.3$. HRMS: calcd for $\mathrm{C}_{11} \mathrm{H}_{7} \mathrm{~N}_{3} \mathrm{O}\left([\mathrm{M}+\mathrm{H}]^{+}\right)$198.0667, found 198.0672.

Pharmacology. Applying the agar plate diffusion technique, ${ }^{32}$ the compounds were screened in vitro for their bactericidal activity against Gram positive bacteria (Staphylococcus aureus) and Gram negative bacteria (Escherichia Coli and Pseudomonas aeroginosa), and for their fungicidal activity against Fusarium, Aspergillus niger and Candida albicans. In this method, a standard $5 \mathrm{~mm}$ diameter sterilized filter paper disc impregnated with the compound $(0.3 \mathrm{mg} / 0.1 \mathrm{ml}$ of DMF) was placed on an agar plate seeded with the test organism. The plates were incubated for 24 hours at $37^{\circ} \mathrm{C}$ for bacteria and $28^{\circ} \mathrm{C}$ for fungi. The zone of inhibition of bacterial and fungi growth around the disc was observed.

The compounds were tested against a liver carcinoma cell line (HEPG2), a human breast carcinoma cell line (MCF7), and a cervix carcinoma cell line (HELA). The method applied is similar to that reported by Skehan et al. ${ }^{41}$ using 20 Sulfo-Rhodamine-B stain (SRB). Cells were plated in 96-multiwell plate (104 cells/well) for $24 \mathrm{~h}$ before treatment with the test compound to allow attachment of cell to the wall of the plate. Different concentrations of the compound under test $(0,1.0,2.5,5.0$, and 10 $\mu \mathrm{g} / \mathrm{ml}$ ) were added to the cell monolayer in triplicate wells individual dose, and monolayer cells were incubated with the compounds for $48 \mathrm{~h}$ at $37^{\circ} \mathrm{C}$ and in atmosphere of $5 \% \mathrm{CO}_{2}$. After $48 \mathrm{~h}$, cells were fixed, washed and stained with SRB stain, excess stain was washed with acetic acid and attached stain was recovered with Tris-EDTA buffer. Color intensity was measured in an ELISA reader, and the relation between surviving fraction and drug concentration is plotted to get the survival curve of each tumor cell line after the specified compound and the $\mathrm{IC}_{50}$ was calculated.

Acknowledgment. We are grateful to Région Bretagne (France) and to MESRS (Algeria) for financial support to G. B, and to MESR (France) for financial support to T. T. N. We thank Rennes Métropole. We are also grateful to Faculty of Women, Ain Shams University, and National Institute of Cancer, Cairo University (Egypt) for pharmacological measurements. 
Supporting Information Available: General procedures and copies of the ${ }^{1} \mathrm{H}$ and ${ }^{13} \mathrm{C}$ NMR spectra for compounds 5a-c, 6a-d, 7, 8, 10, 15-18, 20, 23, 28-33. This material is available free of charge via the Internet at http://pubs.acs.org.

\section{References and Footnotes}

(1) (a) Katritzky, A. R. Handbook of Heterocyclic Chemistry, $1^{\text {st }}$ ed.; Pergamon: New York, NY, 1985. (b) Eicher, T.; Hauptmann, S.; Speicher, A. The Chemistry of Heterocycles, $2^{\text {nd }}$ ed., Wiley-VCH, 2003, Chapter 6.

(2) (a) Quéguiner, G.; Marsais, F.; Snieckus, V.; Epsztajn, J. Adv. Heterocycl. Chem. 1991, 52, 187-304. (b) Mongin, F.; Quéguiner, G. Tetrahedron 2001, 57, 4059-4090. (c) Turck, A.; Plé, N.; Mongin, F.; Quéguiner, G. Tetrahedron 2001, 57, 4489-4505. (d) Schlosser, M.; Mongin, F. Chem. Soc. Rev. 2007, 36, 1161-1172; (e) Chevallier, F.; Mongin, F. Chem. Soc. Rev. 2008, 37, 595-609.

(3) (a) Schlecker, W.; Huth, A.; Ottow, E.; Mulzer, J. J. Org. Chem. 1995, 60, 8414-8416. (b) Schlecker, W.; Huth, A.; Ottow, E.; Mulzer, J. Liebigs Ann. Chem. 1995, 1441-1446. (c) Schlecker, W.; Huth, A.; Ottow, E.; Mulzer, J. Synthesis 1995, 1225-1227.

(4) Schlosser, M. Pure Appl. Chem. 1988, 60, 1627-1634.

(5) Lochmann, L. Eur. J. Inorg. Chem. 2000, 7, 1115-1126.

(6) Caubère, P. Chem. Rev. 1993, 93, 2317-2334.

(7) Gros, P.; Fort, Y. Eur. J. Org. Chem. 2002, 3375-3383.

(8) For reviews, see: (a) Mulvey, R. E. Organometallics 2006, 25, 1060-1075; (b) Mulvey, R. E.; Mongin, F.; Uchiyama, M.; Kondo, Y. Angew. Chem. Int. Ed. 2007, 46, 3802-3824; (c) Mulvey, R. E. Acc. Chem. Res. 2009, $42,743-755$. 
(9) (a) Kondo, Y.; Shilai, M.; Uchiyama, M.; Sakamoto, T. J. Am. Chem. Soc. 1999, 121, 3539-3540. (b) Uchiyama, M.; Miyoshi, T.; Kajihara, Y.; Sakamoto, T.; Otani, Y.; Ohwada, T.; Kondo, Y. J. Am. Chem. Soc. 2002, 124, 8514-8515. (c) Barley, H. R. L.; Clegg, W.; Dale, S. H.; Hevia, E.; Honeyman, G. W.; Kennedy, A. R.; Mulvey, R. E. Angew. Chem. Int. Ed. 2005, 44, 6018-6021. (d) Clegg, W.; Dale, S. H.; Hevia, E.; Honeyman, G. W.; Mulvey, R. E. Angew. Chem. Int. Ed. 2006, 45, 2370-2374. (e) Clegg, W.; Dale, S. H.; Harrington, R. W.; Hevia, E.; Honeyman, G. W.; Mulvey, R. E. Angew. Chem. Int. Ed. 2006, 45, 2374-2377. (f) Clegg, W.; Dale, S. H.; Drummond, A. M.; Hevia, E.; Honeyman, G. W.; Mulvey, R. E. J. Am. Chem. Soc. 2006, 128, 7434-7435. (g) Uchiyama, M.; Kobayashi, Y.; Furuyama, T.; Nakamura, S.; Kajihara, Y.; Miyoshi, T.; Sakamoto, T.; Kondo, Y.; Morokuma, K. J. Am. Chem. Soc. 2008, 130, 472-480. (h) Clegg, W.; Conway, B.; Hevia, E.; McCall, M. D.; Russo, L.; Mulvey, R. E. J. Am. Chem. Soc. 2009, 131, 2375-2384.

(10) (a) Wunderlich, S. H.; Knochel, P. Angew. Chem. Int. Ed. 2007, 46, 7685-7688. (b) Wunderlich, S.; Knochel, P. Chem. Commun. 2008, 6387-6389. (c) Wunderlich, S. H.; Knochel, P. Org. Lett. 2008, 10, 47054707. (d) Mosrin, M.; Knochel, P. Chem. Eur. J. 2009, 15, 1468-1477.

(11) Mosrin, M.; Knochel, P. Org. Lett. 2009, 11, 1837-1840.

(12) (a) Uchiyama, M.; Naka, H.; Matsumoto, Y.; Ohwada, T. J. Am. Chem. Soc. 2004, 126, 10526-10527. (b) Garcia-Alvarez, J.; Graham, D. V.; Kennedy, A. R.; Mulvey, R. E.; Weatherstone, S. Chem. Commun. 2006, 30, 3208-3210. (c) Garcia-Alvarez, J.; Hevia, E.; Kennedy, A. R.; Klett, J.; Mulvey, R. E. Chem. Commun. 2007, 2402-2404. (d) Conway, B.; Hevia, E.; García-Álvarez, J.; Graham, D. V.; Kennedy, A. R.; Mulvey, R. E. Chem. Commun. 2007, 5241-5243. (e) Naka, H.; Uchiyama, M.; Matsumoto, Y.; Wheatley, A. E. H.; McPartlin, M.; Morey, J. V.; Kondo, Y. J. Am. Chem. Soc. 2007, 129, 1921-1930. (f) Naka, H.; Morey, J. V.; Haywood, J.; Eisler, D. J.; McPartlin, M.; Garcia, F.; Kudo, H.; Kondo, Y.; Uchiyama, M.; Wheatley, A. E. H. J. Am. Chem. Soc. 2008, 130, 16193-16200.

(13) Wunderlich, S. H.; Knochel, P. Angew. Chem. Int. Ed. 2009, 48, 1501-1504. 
(14) Garcia-Álvarez, J.; Kennedy, A. R.; Klett, J.; Mulvey, R. E. Angew. Chem. Int. Ed. 2007, 46, 1105-1108.

(15) Usui, S.; Hashimoto, Y.; Morey, J. V.; Wheatley, A. E. H.; Uchiyama, M. J. Am. Chem. Soc. 2007, 129, 15102-15103.

(16) (a) L'Helgoual'ch, J.-M.; Bentabed-Ababsa, G.; Chevallier, F.; Yonehara, M.; Uchiyama, M.; Derdour, A.; Mongin, F. Chem. Commun. 2008, 5375-5377. (b) L'Helgoual'ch, J.-M.; Bentabed-Ababsa, G.; Chevallier, F.; Derdour, A.; Mongin, F. Synthesis 2008, 4033-4035. (c) Bentabed-Ababsa, G.; Blanco, F.; Derdour, A.; Mongin, F.; Trécourt, F.; Quéguiner, G.; Ballesteros, R.; Abarca, B. J. Org. Chem. 2009, 74, 163-169. (d) Snégaroff, K.; L'Helgoual'ch, J.-M.; Bentabed-Ababsa, G.; Nguyen, T. T.; Chevallier, F.; Yonehara, M.; Uchiyama, M.; Derdour, A.; Mongin, F. Chem. Eur. J. 2009, 15, 10280-10290.

(17) $\mathrm{CdCl}_{2} \cdot$ TMEDA can be prepared in large amounts $(\sim 20 \mathrm{~g})$, and stored for several months in a desiccator, whereas free $\mathrm{CdCl}_{2}$ has to be heated with a heat gun under vacuum for $30 \mathrm{~min}$ before each use.

(18) (a) Krizan, T. D.; Martin, J. C. J. Org. Chem. 1982, 47, 2681-2682. (b) Krizan, T. D.; Martin, J. C. J. Am. Chem. Soc. 1983, 105, 6155-6157.

(19) Pletnev, A. A.; Tian, Q.; Larock, R. C. J. Org. Chem. 2002, 67, 9276-9287.

(20) Using $\mathrm{Me}_{3} \mathrm{SiCl}$ and $\mathrm{I}_{2}$ as electrophile, difunctionalized derivatives concomitantly formed, probably through an homotransmetalation type mechanism: Mallet, M.; Quéguiner, G. Tetrahedron 1985, 16, 3433-3440.

(21) (a) Cailly, T.; Fabis, F.; Lemaître, S.; Bouillon, A.; Rault, S. Tetrahedron Lett. 2005, 46, 135-137. (b) Cailly, T.; Fabis, F.; Bouillon, A.; Lemaître, S.; Sopkova, J.; de Santos, O.; Rault, S. Synlett 2006, 53-56. See also: (c) Cailly, T.; Fabis, F.; Rault, S. Tetrahedron 2006, 62, 5862-5867. An in situ deprotonation-trapping protocol has also been used for the synthesis of the corresponding boronic esters: (d) Hansen, H. M.; Lysén, M.; Begtrup, M.; Kristensen, J. L. Tetrahedron 2005, 61, 9955-9960; (e) Cailly, T.; Lemaître, S.; Fabis, F.; Rault, S. Synthesis 2007, 3247-3251. Note that butyllithium in a mixture of THF and hexane has also been used, albeit in 
a low yield, to metalate 4-cyanopyridine at the 2 position: (f) Su, Y.-J.; Ko, C.-W. Chinese Pat. 2005, CN 1616471.

(22) Ethyl thiophene-2-carboxylate (9) has previously been metalated using ${ }^{\mathrm{i}} \mathrm{Pr}_{2} \mathrm{NMgCl}$ (2 equiv) in $\mathrm{THF}$ at room temperature for $10 \mathrm{~min}$, and trapped with iodine to provide the iodide $\mathbf{1 0}$ in 77\% yield: Shilai, M.; Kondo, Y.; Sakamoto, T. J. Chem. Soc., Perkin Trans. 1 2001, 442-444.

(23) Clososki, G. C.; Rohbogner, C. J.; Knochel, P. Angew. Chem. Int. Ed. 2007, 46, 7681-7684.

(24) Cristau, H.-J.; Cellier, P. P.; Spindler, J.-F.; Taillefer, M. Eur. J. Org. Chem. 2004, 695-709.

(25) Begouin, A.; Hesse, S.; Queiroz, M. J. R. P.; Kirsch, G. Synthesis 2006, 2794-2798.

(26) Vaidya, N. A.; Panos, C. H.; Kite, A.; Ben Iturrian, W.; De Witt Blanton, C. J. Med. Chem. 1983, 26, $1422-1425$.

(27) White, D. C.; Greenwood, T. D.; Downey, A. L.; Bloomquist, J. R.; Wolfe, J. F. Bioorg. Med. Chem. Lett. 2004, 5711-5717.

(28) Johnson, M.; Li, A.-R.; Liu, J.; Fu, Z.; Zhu, L.; Miao, S.; Wang, X.; Xu, Q.; Huang, A.; Marcus, A.; Xu, F.; Ebsworth, K.; Sablan, E.; Danao, J.; Kumer, J.; Dairaghi, D.; Lawrence, C.; Sullivan, T.; Tonn, G.; Schall, T.; Collins, T.; Medina, J. Bioorg. Med. Chem. Lett. 2007, 3339-3343.

(29) (a) Scovill, J.; Blank, E.; Konnick, M.; Nenortas, E.; Shapiro, T. Antimicrobial Agents and Chemotherapy 2002, 46, 882-883. (b) Bhattacharjee, A. K.; Skancky, D. J.; Jennings, B.; Hudson, T. H.; Brendle, J. J.; Werbovetz, K. A. Bioorg. Med. Chem. 2002, 10, 1979-1989.

(30) Bhattacharjee, A. K.; Geyer, J. A.; Woodard, C. L.; Kathcart, A. K.; Nichols, D. A.; Prigge, S. T.; Mott, B. T.; Waters, N. C. J. Med. Chem. 2004, 47, 5418-5426. 
(31) Rylowski, A.; Pucko, W. Acta Poloniae Pharmaceutica 1997, 54, 325-330.

(32) Bauer, A. W.; Mkriby, W. W.; Sherris, J. C.; Turck, M. Am. J. Clin. Pathol. 1966, 45, 493.

(33) Shannon, M. Heavy Metal Poisoning in Clinical Management of Poisoning and Drug Overdose, $3^{\text {rd }}$ ed. (Eds: Haddad, L. M.; Shannon, M.; Winchester, J. F.), 1998. The use of salts reduces the risk of cadmium absorption.

(34) L'Helgoual'ch, J.-M.; Seggio, A.; Chevallier, F.; Yonehara, M.; Jeanneau, E.; Uchiyama, M.; Mongin, F. J. Org. Chem. 2008, 73, 177-183, and references cited therein.

(35) $\mathrm{CdCl}_{2} \cdot$ TMEDA was prepared as described: Kedarnath, G.; Kumbhare, L. B.; Jain, V. K.; Phadnis, P. P.; Nethaji, M. Dalton Trans. 2006, 2714-2718.

(36) Jones, P.; Kinzel, O.; Llauger Bufi, L.; Muraglia, E.; Pescatore, G.; Torrisi, C. PCT Int. Appl. 2007, WO 2007138355.

(37) Rodgers, J. D.; Robinson, D. J.; Arvanitis, A. G.; Maduskuie, T. P., Jr.; Shepard, S.; Storace, L.; Wang, H.; Rafalski, M.; Jalluri, R. K.; Combs, A. P. PCT Int. Appl. 2005, WO 2005105814.

(38) Giblin, G. M. P.; Hall, A.; Hurst, D. N. PCT Int. Appl. 2005, WO 2005037794.

(39) Storm, O.; Lüning, U. Eur. J. Org. Chem. 2002, 3680-3685.

(40) Rylowski, A.; Pucko, W. Acta Poloniae Pharmaceutica 1997, 54, 325-330.

(41) Skehan, P.; Storeng, R.; Scudiero, D.; Monks, A.; McMahon, J.; Vistica, D.; Warren, J. T.; Bokesch, H.; Kenney, S.; Boyd, M. R. J. Natl. Cancer Inst. 1990, 82, 1107-1112. 